\title{
p43, the protein product of the atypical insertion sequence IS900, is expressed in Mycobacterium paratuberculosis
}

\author{
Mark L. V. Tizard, ${ }^{*}$ Michael T. Moss, Jeremy D. Sanderson, Brian M. Austen and \\ JOHN HERMON-TAYLOR
}

Department of Surgery, St George's Hospital Medical School, Cranmer Terrace, London SWI7 ORE, UK

(Received 28 February 1992; revised 13 April 1992; accepted 24 April 1992)

\begin{abstract}
The novel mycobacterial insertion sequence IS900 was analysed by coupled transcription-translation, of both strands independently, in a cell-free $E$. coli extract using an exogenous promoter. This revealed only one protein product, p43, as predicted from the nucleotide sequence. The protein was readily translated in recombinant $E$. coli, using the tac promoter, though it did not appear as a major product by SDS-PAGE analysis. A synthetic peptide was used to generate and affinity-purify a specific anti-p43 antibody, which clearly identified the protein in recombinant $E$. coli. p43 was relatively stable in exponential phase and stationery phase bacteria, though a $28 \mathrm{kDa}$ processed form was seen to accumulate over a period of hours. Both forms appeared in the soluble fraction of the bacterial lysate. The anti-p43 antibody also identified $\mathrm{p} 43$, as a $28 \mathrm{kDa}$ processed product, in Western blots of protein extracts from Mycobacterium paratuberculosis, indicating a level of expression which would be unusually high for a classical transposase. These data have important implications for the relationship between IS900 and its host.
\end{abstract}

\section{Introduction}

Diagnosis of Mycobacterium paratuberculosis infection in ruminants, causing the chronic enteritis Johne's disease, is of veterinary and economic importance. This is also of relevance to research into the cause of a similar chronic enteritis Crohn's disease in humans (Hermon-Taylor et al., 1990). Recent research into Johne's disease and Crohn's disease has utilized DNA probes based on IS900 (Moss et al., 1991; Vary et al., 1990; Sanderson et al., 1992) and ELISAs based on mixed bacterial antigen (Tanaka et al., 1990; Collins et al., 1991). The gene product of IS $900, \mathrm{p} 43$, represents the first sequencedefined specific antigen from $M$. paratuberculosis and as such has a potential use in the diagnosis of Johne's disease. In addition, IS 900 shows some unusual features for an insertion sequence, the basis of which may be revealed by studying the functions of $\mathbf{p 4 3}$.

Insertion sequences (IS) are small units of DNA (approximately $700-2500 \mathrm{bp}$ ) that are usually able to transpose from one genetic locus to another, on the same replicon or between replicons. IS 900 was the first IS element identified in a mycobacterium, from $M$. paratuberculosis (Green et al., 1989). Other elements were later

* Author for correspondence. Tel. (081) 7677631 ; fax (081) 784 2694/(081) 7674696. identified in $M$. tuberculosis (Hermans et al., 1990; Thierry et al., 1990), M. leprae (Clark-Curtiss \& Docherty, 1989) and M. fortuitum (Martin et al., 1990). Sequence analysis of the IS elements identified in $M$. tuberculosis and $\boldsymbol{M}$. fortuitum showed that they were related to the IS 3 and IS6 groups, respectively, found in Gram-negative organisms, and both possessed the classical terminal inverted and direct repeat sequences. Two other elements have recently been identified in $M$. smegmatis, IS6120 and IS1096, both of which have been completely sequenced and possess terminal inverted repeats and contain two overlapping open reading frames (Guilhot et al., 1992; Cirillo et al., 1992).

IS 900 is $1451 \mathrm{bp}$ in length with a single open reading frame, ORF1197, from nucleotides 236 to 1433 starting with a GTG initiation codon and preceeded at nucleotide 226 by a Shine-Dalgarno (S-D) sequence GGAGG (Green et al., 1989). IS900 is unusual in that it does not possess either of the terminal repeat structures which are characteristic of IS elements. This is significant because inverted repeat structures are known to be functionally important in transposition events (Huang et al., 1986; New et al., 1988). Specific interaction between established transposase proteins and their respective terminal inverted repeat sequences has been demonstrated for transposons Tn3 (Wishart et al., 1985), $\gamma \delta$ (Wiater \& 
Grindley, 1991) and Tn10 (Morisato \& Kleckner, 1984). Another unusual feature of IS 900 is that it has a specific target sequence into which it inserts in a specific orientation (Green et al., 1989). Tn554, from Staphylococcus, also shows these characteristics, including the lack of terminal repeats (Murphy, 1988); it is, however, much larger and more complex, encoding three proteins $(14,43$ and $74 \mathrm{kDa})$ essential for transposition. Another transposon exhibiting orientation and site-specific insertion is Tn7, from E. coli. Transposition of this element has been shown to require the formation of a nucleoprotein complex involving two molecules of DNA and at least four transposon-encoded proteins (TnsA $31 \mathrm{kDa}$, TnsB $81 \mathrm{kDa}$, TnsC $62 \mathrm{kDa}$ and TnsD $59 \mathrm{kDa}$ ) and probably one or more host-encoded products (Bainton $e t$ al., 1991). These characteristics are found only in a few mobile elements which, with the exception of IS 900 (small and encoding only one $43 \mathrm{kDa}$ protein), are all large and complex. The IS900 protein (possibly in concert with host-encoded factors) appears to function in an analogous manner to the components encoded by the more complex transposons $\mathrm{Tn} 7$ and $\mathrm{Tn} 554$.

An engineered mycobacterial site-specific recombination system has recently been used to mediate stable integration of foreign genes into $M$. bovis BCG, exploiting the adjuvant activity of this organism to create novel vaccine strains (Stover et al., 1991). The demonstration that IS900 can promote integration of an antibiotic resistance marker in mycobacteria highlights the potential for development of this system (England $e t$ al., 1991). A defined recombination system, with the unique characteristics exhibited by IS 900 , would be another useful tool for the molecular genetic manipulation of mycobacteria. Definition of the mechanism controlling transposition of IS900 is essential for construction of vectors analogous to mini Tn10 (Petit et al., 1990), which can mediate controllable, terminal integrations. To investigate this mechanism we have studied translation of the single open reading frame in vitro and in vivo, establishing a source of recombinant protein for purification and functional analysis.

\section{Methods}

Mycobacteria. Four $M$. paratuberculosis strains were isolated from cattle, a deer and a goat suffering chronic enteritis (kindly supplied by Dr W. Donachie, Moredun Institute, Edinburgh, UK). $M$. avium subsp. silvaticum strains were isolated from deer suffering chronic enteritis. $M$. avium strains were isolated from an AIDS patient suffering intestinal mycobacteriosis. The latter were cultured in Middlebrook 7 H9 medium supplemented with $0.02 \%$ glycerol and ADC (Difco) at $30^{\circ} \mathrm{C}$ with shaking. The former were cultured under the same conditions in media supplemented with $1 \mu \mathrm{g}$ mycobactin $\mathrm{J}$ (Rhone Merieux) $\mathrm{ml}^{-1}$.
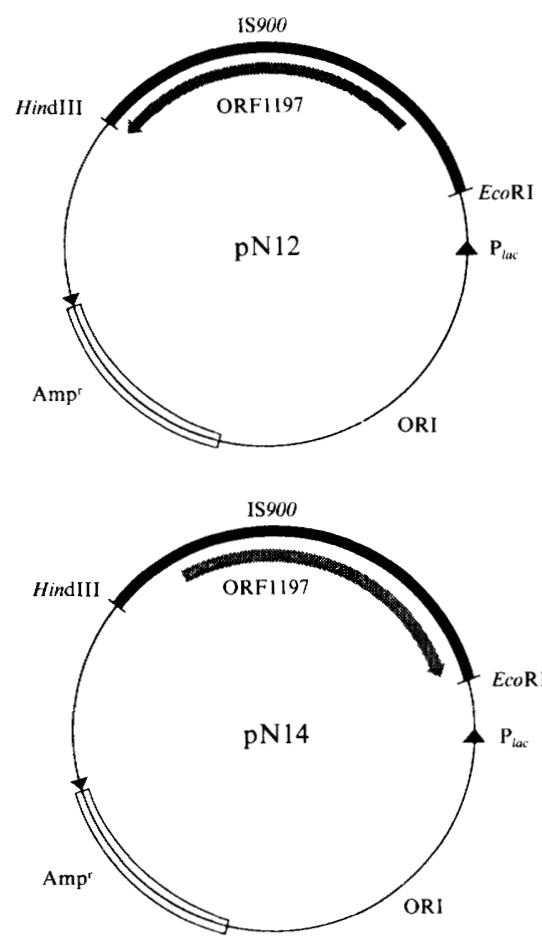

Fig. 1. Circular maps of the plasmids $\mathrm{pN} 12$ and $\mathrm{pN} 14$, which contain IS900, showing the orientations of the open reading frame ORF1197 with respect to the lac promoter in the vector pUC18.

Recombinant DNA methods. All plasmids were maintained in E. coli XL-1 (Stratagene). Recombinants were selected and maintained by growth on Luria-Bertani medium agar with $100 \mathrm{mg}$ ampicillin $\mathrm{ml}^{-1}$, at $37^{\circ} \mathrm{C}$. Plasmid DNA for restriction analysis and in vitro transcriptiontranslation was isolated by alkaline lysis coupled with purification by the Qiagen method (Diagen $\mathrm{GmbH}$ ).

Conventional DNA manipulations were performed as described by Sambrook et al. (1989). DNA fragments were purified from agarose gels for use in ligation using Geneclean (Bio 101 Inc.). All restriction enzymes and DNA modification enzymes were used according to the manufacturer's specifications (NBL).

Construction of plasmids. A $1.5 \mathrm{kbp}$ NruI fragment from the plasmid pMB22 containing IS900 (McFadden et al., 1987a) was cloned into the Smal site of pUC18. This fragment contains the full sequence of IS 900 with $66 \mathrm{bp}$ of $5^{\prime}$ flanking sequence and $8 \mathrm{bp}$ of $3^{\prime}$ flanking sequence derived from the $M$. paratuberculosis genome (Green et al., 1989). This generated two orientations of the fragment: $\mathrm{pN} 12$ with the coding strand for ORF1197 transcribed from the lac promoter, and pN14 with the antisense strand for ORF1197 transcribed from the lac promoter (Fig. 1).

In other constructs, coding sequences were placed under control of the tac promoter in the vector pDEV19 (a gift from Dr Rayment, Wellcome Research Laboratories, Beckenham, UK), which carries ampicillin resistance, $\operatorname{lacZ}$ with an EcoRI-BamHI cloning site at the amino-terminus and $\mathrm{lacl} \mathrm{I}^{\mathrm{q}}$. The $5^{\prime}$ non-coding region of IS900 was deleted with $B a l 31$ nuclease prior to cloning. Two clones were selected: pDI13 representing a transcriptional fusion of ORF1197 to $P_{t a c}$ and pDI9 representing a translational fusion of the first 10 codons of lac $Z$ to codon 8 of ORF1197.

In vitro transcription-translation. Supercoiled plasmids were used as template to direct coupled transcription-translation in a cell-free $30 \mathrm{~S} E$. 
coli extract (Amersham): $0.5-1.0 \mathrm{mg}$ of template was used and translation followed by incorporation of $\left[{ }^{35}\right.$ S $]$ methionine (ICN) according to the manufacturer's protocol. Proteins were analysed by SDS-PAGE (Laemmli, 1970) on a $10 \%(\mathrm{w} / \mathrm{v}$, acrylamide) gel, which was dried and subject to autoradiography.

Preparation of bacterial protein extracts. Recombinant $E$. coli were grown to an $\mathrm{OD}_{550}$ of 0.3 then induced by addition of isopropyl $\beta$-Dgalactopyranoside (NBL) to $120 \mathrm{mg} \mathrm{ml}^{-1}$ final concentration. Cultures were sampled at various intervals. Cells were harvested and lysed with lysozyme (Sigma) then treated with DNAaseI (Sigma). Protein extracts were analysed by SDS-PAGE followed either by staining with Coomassie brilliant blue or by transfer to BAS nitrocellulose (Schleicher and Schuell) using a SartoblotII semi-dry electroblotter (Sartorius) according to the manufacturer's protocol.

Mycobacterial protein extracts were prepared by boiling the harvested cell pellet in SDS loading buffer $(1.5 \%, \mathrm{w} / \mathrm{v}, \mathrm{SDS}, 0.18 \mathrm{M}$ Tris $/ \mathrm{HCl}, \mathrm{pH} 6.5,15 \%$, v/v, glycerol, $10 \mathrm{~mm}-\mathrm{DTT}, 0.05 \%$ bromophenol blue) followed by sonication for $1 \mathrm{~min}$ to shear released DNA. Extracts were analysed as described above.

Preparation of p43-specific anti-peptide antibody. Computer analysis of ORF1197 was used to identify charged regions with turning structural characteristics using Staden-Plus (Amersham) to favour the selection of hydrophilic surface loops which may be antigenic/immunogenic. A region of ORF1197 representing Tyr95 to Asp112, designated CP-1 (YRGEGKTDAKDAAIIAD) was synthesized using FMOC protection chemistry. An additional carboxy-terminal cysteine was added to allow coupling to solid phase. The peptide was purified by HPLC and validated by amino acid analysis and mass spectrometry. This reagent was used to hyperimmunize two New Zealand White rabbits. CP-1 was coupled to Sepharose CL-4B (Pharmacia). The immobilized peptide was used to affinity-purify anti-peptide antibodies from immune sera with ELISA titres greater than $1: 3000$. Pre-immune sera from both rabbits were negative when assayed by ELISA, and failed to recognize any specific bands in Western blots of protein extracted from recombinant $E$. coli or $M$. paratuberculosis.

Immunostaining of Western blots. The purified antibody reagent was used at a working dilution of $1: 2000$ in TBST $(50 \mathrm{~mm}$-Tris/ $\mathrm{HCl}$, $\mathrm{pH} 7.6,150 \mathrm{~mm}-\mathrm{NaCl}, 0.05 \%$ Tween 20 ), using $10 \%$ (w/v) dried skimmed milk as blocking agent. Second layer antibody was goat(antirabbit Ig)-horseradish peroxidase conjugate (Sigma) used at a $1: 1000$ dilution. Staining was revealed with hydrogen peroxide and 3-amino-9ethylcarbazole (Sigma), or using ECL substrate (Amersham) combined with autoradiography according to the manufacturer's protocol

\section{Results}

\section{Transcription-translation of both strands of IS900}

Coupled in vitro transcription-translation of the plasmid template pN12 (Fig. 2, lane 2) suggested that the predicted $\mathrm{S}-\mathrm{D}$ sequence and open reading frame ORF1197 (Green et al., 1989) were functional in an $E$. coli $30 \mathrm{~S}$ cell free extract. Migration of the protein product, designated $\mathrm{p} 43$, indicated an apparent molecular mass of $44.5 \mathrm{kDa}$. No specific proteins could be identified in transcription-translation of the opposite strand, from the plasmid template pN14 (Fig. 2, lane 3). A long open reading frame runs antiparallel to ORF1197; however, it lacks S-D sequences adjacent to

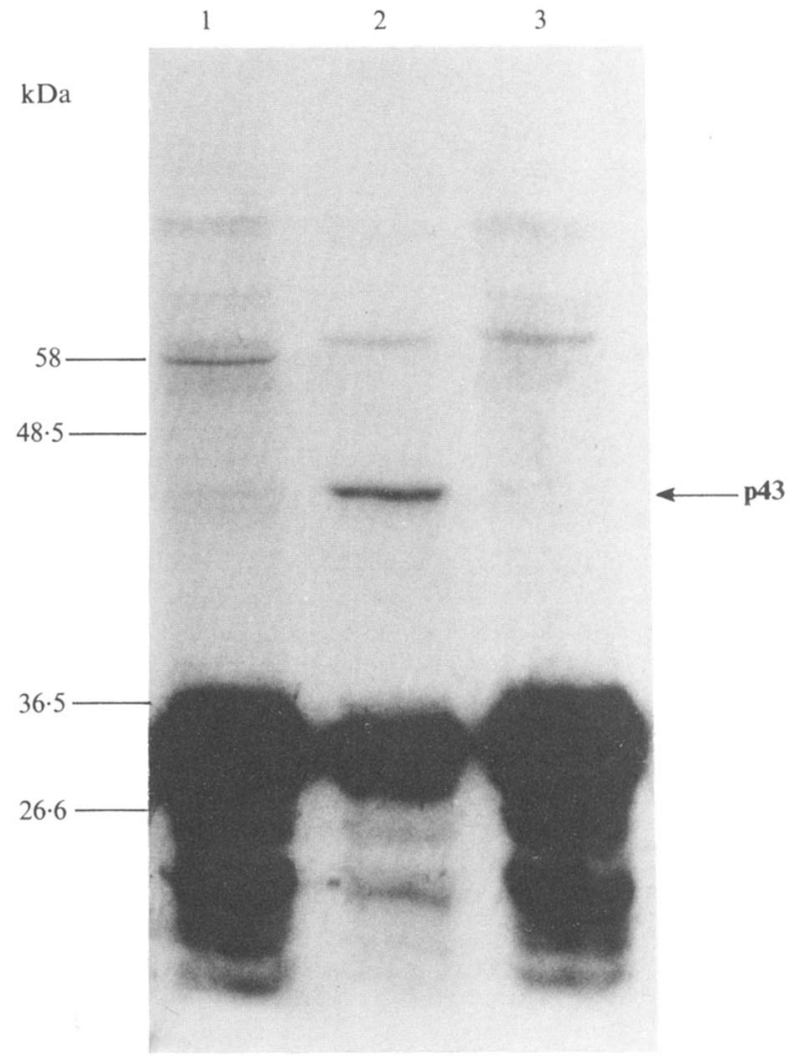

Fig. 2. In vitro transcription-translation of IS900. Supercoiled template DNA $(1 \mu \mathrm{g})$ was used to programme an $E$. coli 30 S cell-free extract. An autoradiograph of $\left.{ }^{[35} \mathrm{S}\right]$ methionine incorporation into proteins produced by the plasmids pUC18 (lane 1), pN12 (lane 2) and pN14 (lane 3). Molecular mass standards are Sigma (SDS 7B) prestained markers.

initiation codons. The molecular mass of pUC18-vectorencoded products (Fig. 2, lane 1) does not coincide with the predicted molecular mass of potential products of the antiparallel open reading frame.

\section{Regulation of in vitro expression of $p 43$}

The putative transcriptional control region of IS 900 upstream of ORF1197 was deleted using Bal31 nuclease. pDI1 3 represented the S-D sequence and codons 1-399 (nucleotides 200-1451) inserted downstream and out of frame with the vector-encoded S-D sequence and ATG initiation codon (Fig. 3). pDI9 represented a fusion of the vector $\mathrm{S}-\mathrm{D}$ sequence and the first 10 codons of the $\operatorname{lac} Z \alpha$ peptide and codons 7-399 (nucleotides 258-1451) of IS 900 (Fig. 3). The full insert from pN12 was cloned into pDEV19 to give pDI12. These four constructs were analysed for comparative levels of expression of $p 43$ and $\beta$-lactamase, as an internal control (Fig. 4). The results of scanning densitometry on autoradiographs from a number of experiments (Table 1) show that the tac 


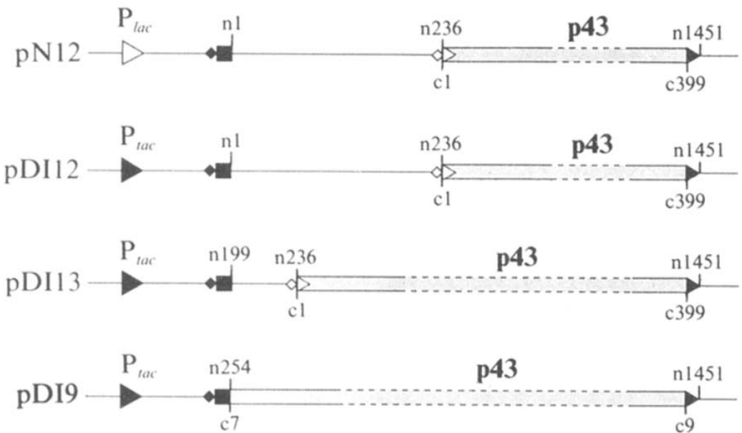

Fig. 3. Modified plasmid templates were prepared to programme in vitro translations. $\mathrm{pN} 12, \mathbf{P}_{\text {lac }}$ (large open triangle) nucleotides $1-1451$, IS900 RBS (open diamond) and GTG codon 1 (small open triangle); pDI12, as pN12 but $\mathbf{P}_{t a c}$ (large solid triangle); pDI13, $\mathbf{P}_{t a c}$ nucleotides 199-1451, IS900 RBS and GTG codon 1; pDI9, $P_{\text {tac }}$ nucleotides $257-$ 1451 (codons 8-399), lacZ RBS (solid diamond) and ATG codon 1 to codon 10 (solid square). IS 900 nucleotide numbers (n) and $\mathbf{p 4 3}$ codon numbers (c) are shown.

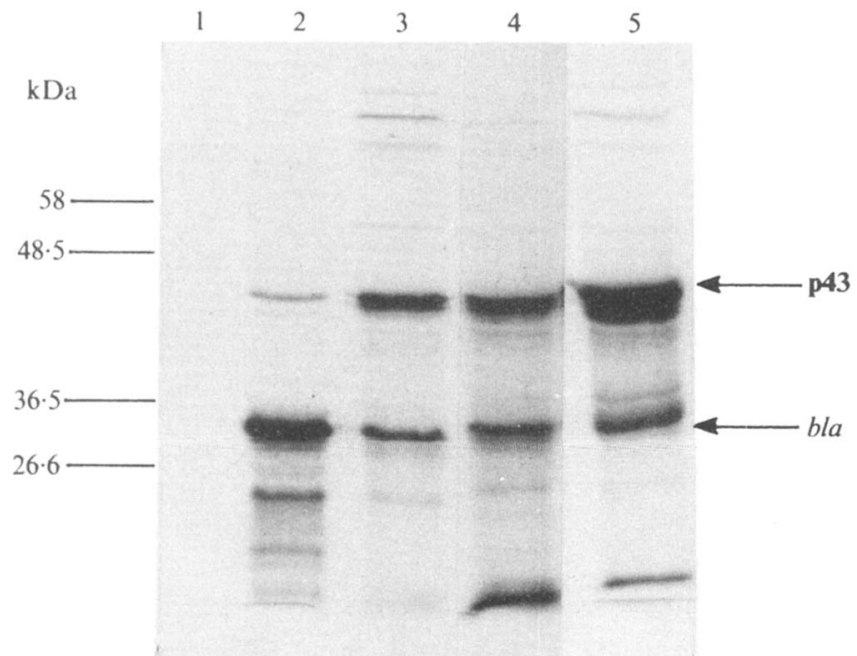

Fig. 4. In vitro transcription-translation of the modified template DNAs. Expression of $\mathbf{p 4 3}$ was analysed comparing regulation by the $l a c$ and tac promoters and with modified translation signals (Fig. 3). Lane 1 , pN12; lane 2, pDI12; lane 3, pDI13; lane 4, pDI9. p43 and $\beta$ lactamase $(b l a)$ are indicated.

Table 1. Relative levels of expression in vitro of $\mathbf{p 4 3}$

\begin{tabular}{lcccc}
\hline \hline Construct & RBS & $\begin{array}{c}\text { Initiation } \\
\text { codon }\end{array}$ & Promoter & $\begin{array}{c}\text { Relative level of } \\
\text { expression of p43* }\end{array}$ \\
\hline pN12 & IS900 & GTG & lac & $0.02 \pm 0.005$ \\
pDI12 & IS900 & GTG & tac & $2 \cdot 36 \pm 0.68$ \\
pDI13† & IS900 & GTG & tac & $2 \cdot 10 \pm 0.38$ \\
pDI9 & lacZ & ATG & tac & $6.67 \pm 0.80$ \\
\hline \hline
\end{tabular}

* Arbitrary units. Measured by scanning densitometry of autoradiographs and defined as the ratio of the optical density of the p43 band to the $\beta$-lactamase band produced by the same plasmid (as an internal control). Results are the mean of four transcription-translations \pm standard error, of which Fig. 4 is representative.

$\dagger$ Lacks the first 199 nucleotides of IS 900 , the putative transcription control region of the element. promoter gives a significantly higher level of expression of $\mathbf{p} 43$ than the lac promoter. Comparing expression of p43 between pDI12 and pDI13 shows that the presence or absence of the region of IS900 (nucleotides 1-199) upstream of the predicted ribosome binding site (RBS) has no significant effect. However, replacement of the p43 translation signals, the RBS and the first seven codons including the GTG initiation codon, in pDI9 with optimized $E$. coli translation signals increased the level of expression threefold.

With the stronger tac promoter, expression yields an additional band which migrates slightly faster than $\mathbf{p 4 3}$, corresponding to a lower molecular mass with a difference of $<1.0 \mathrm{kDa}$. This product represents approximately $50 \%$ of the higher molecular mass product and is produced by both pDI12 and pDI13. The primary product of pDI9 is of slightly higher molecular mass than p43 (due to the amino-terminal modification), there is a second product with an equivalent $1.0 \mathrm{kDa}$ molecular mass difference (approximately $20 \%$ of the primary product) and a third product with an apparent molecular mass slightly lower still (approximately $30 \%$ of the primary product). There are no potential signal sequences at the amino-terminus of p43 which might explain these observations.

\section{Over-expression of $\mathrm{p43}$ in vivo}

SDS-PAGE analysis of IPTG-induced bacterial lysates of hosts carrying pDI13 (Fig. 5a) shows a protein with a molecular mass of approximately $45 \mathrm{kDa}$ accumulating during a time-course of up to $2 \mathrm{~h}$ with no product present in induced lysates from hosts containing the vector (pDEV19) only. Coomassie staining of this gel was carried out after a partial electro-transfer as the band of interest was obscured by a host band of similar molecular mass, but which electro-transferred at a higher rate (data not shown).

\section{Anti-peptide antibody binds p43}

Western blot analysis of the recombinant $E$. coli cell lysates (Fig. $5 b$ ) shows staining $\mathbf{p 4 3}$ with the monospecific antibody. This result confirmed the reading frame and identity of $\mathbf{p 4 3}$, even though the protein migrates with an apparent molecular mass of $45 \mathrm{kDa}$. This disparity is almost certainly due to the high basic character of p43 (predicted pI 10.4), which may retard its migration during SDS-PAGE and clearly reduces its rate of electro-transfer to nitrocellulose.

Of the p43 expressed in $E$. coli, $80-90 \%$ was found in the soluble fraction of the bacterial lysate (data not shown). p43 continued to accumulate to a maximum up to $5 \mathrm{~h}$ after induction of a mid exponential phase culture, 
(a)

\begin{tabular}{|c|c|c|c|c|c|c|c|}
\hline \multicolumn{4}{|c|}{ pDEV } & \multicolumn{4}{|c|}{ pDI13 } \\
\hline Time ... 0 & 30 & 60 & 120 & 0 & 30 & & \\
\hline
\end{tabular}

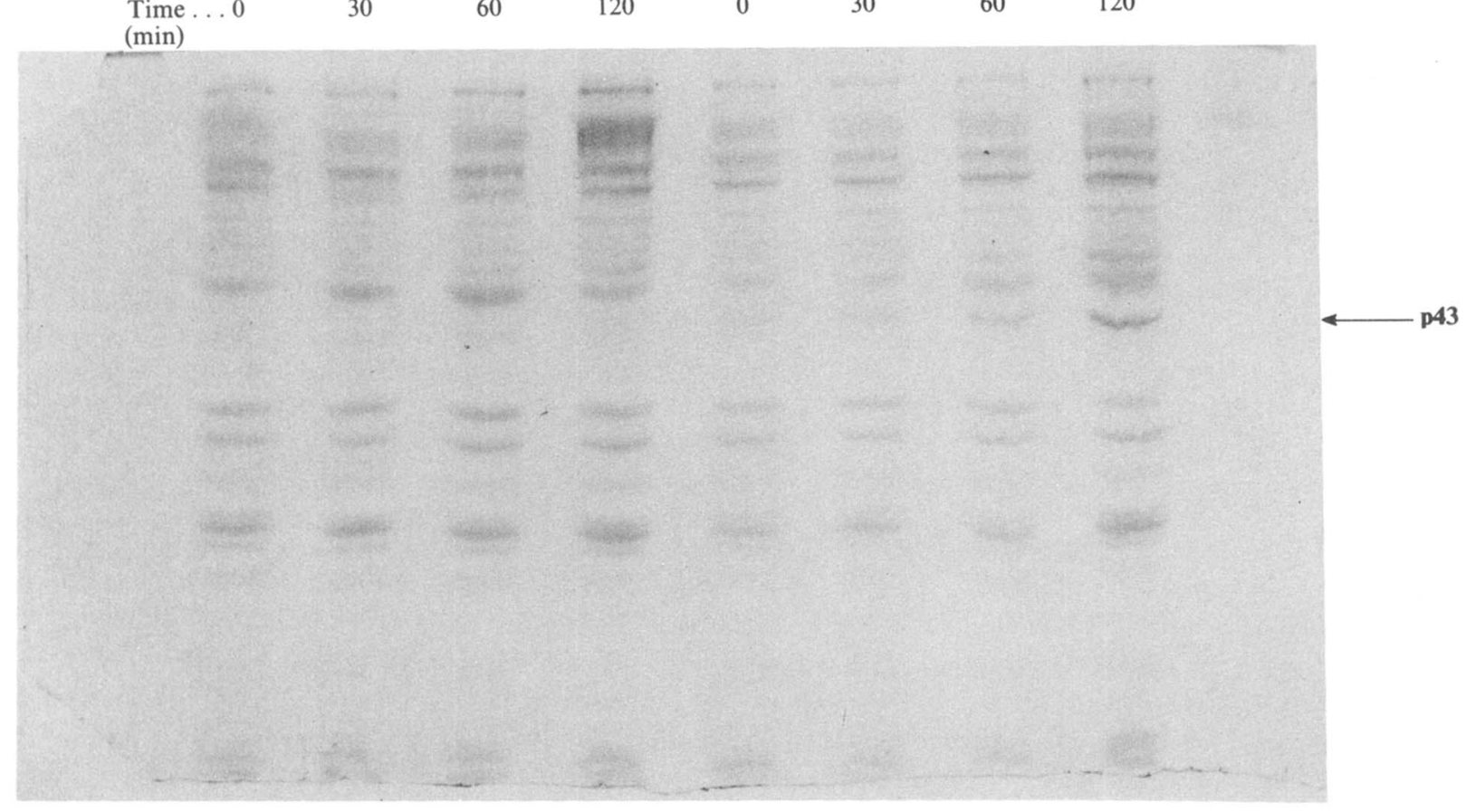

(b)

\begin{tabular}{|c|c|c|c|c|c|c|c|}
\hline \multicolumn{4}{|c|}{$\mathrm{pDEV}$} & \multicolumn{4}{|c|}{ pDI13 } \\
\hline$\underset{(\min )}{\operatorname{Time}} \ldots 0$ & 30 & 60 & 120 & 0 & 30 & 60 & 120 \\
\hline
\end{tabular}

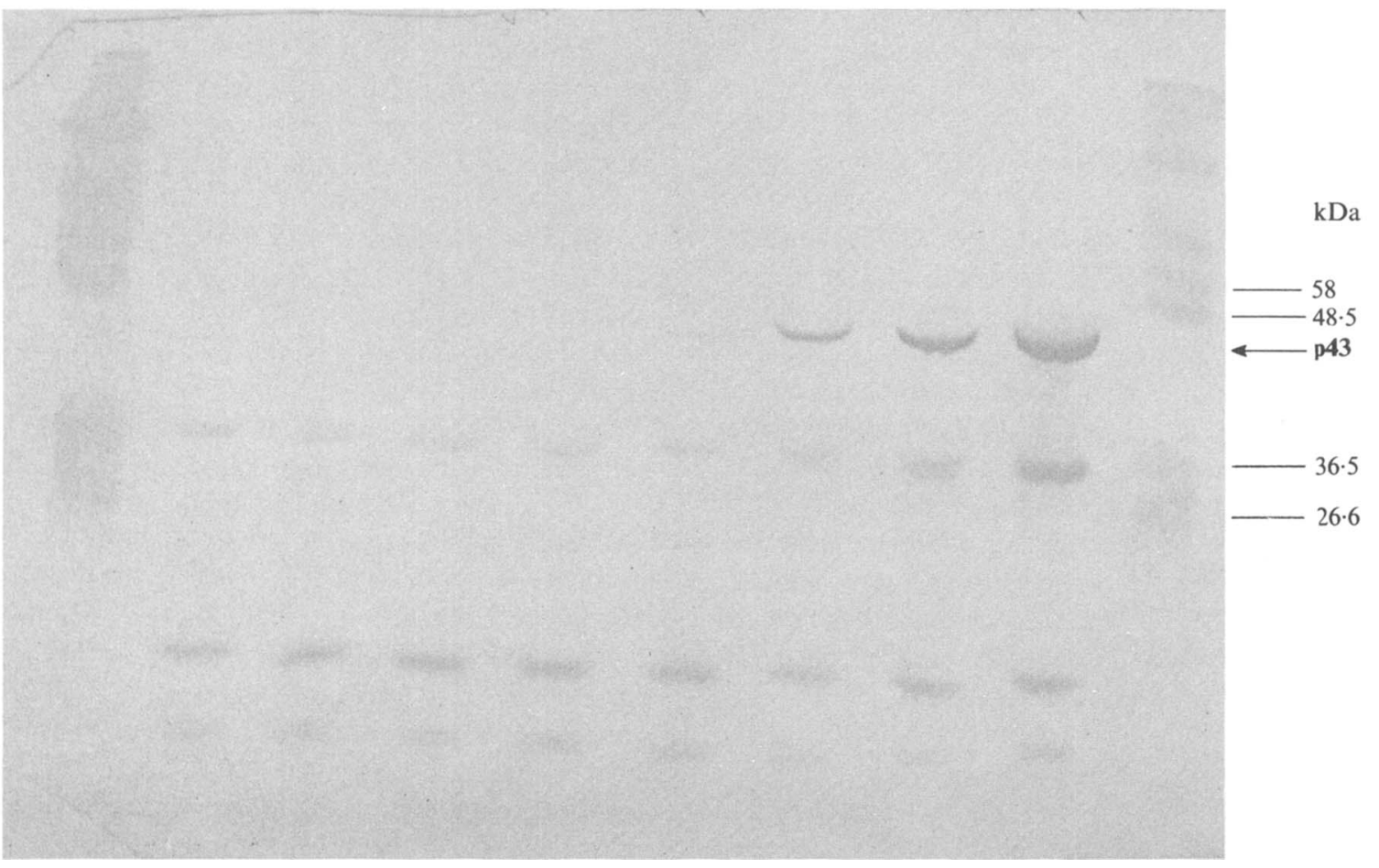

Fig. 5. Detection of recombinant $\mathbf{4 3}$ expression. Protein extracts from recombinant $E$. coli carrying PDI1 3 or pDEV19 were analysed by SDS-PAGE. Samples were taken at $0,30,60$ and $120 \mathrm{~min}$ after induction of expression. (a) Coomassie-stained gel after partial electrotransfer; $(b)$ immunostain with antipeptide antibody after transfer to nitrocellulose; the HRP-conjugate second-layer antibody was revealed by reaction with AEC. 


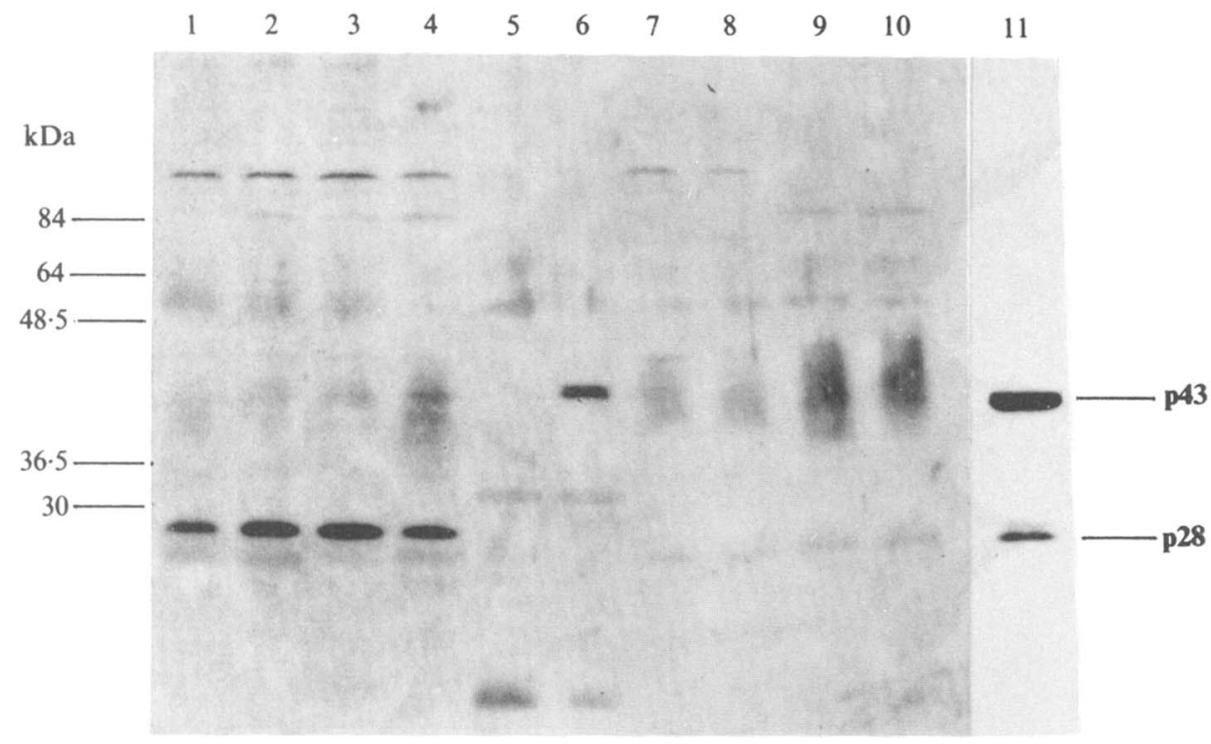

Fig. 6. Detection of $\mathrm{p} 43$ in $M$. paratuberculosis. Western blot and immunostain of protein extracts prepared from $M$. paratuberculosis. Lane 1, bovine isolate 0022 ; lane 2 , bovine isolate 0025 ; lane 3 , deer isolate 0023 ; lane 4, goat isolate 0024; lane 5, E. coli pDEV19; lane 6, E. coli pDI13 after 15 min induced expression; lane 7, $M$. avium isolate 0034; lane 8, $M$. avium isolate 0036 ; lane 9 . $M$. avium subsp. silvaticum isolate 0005 ; lane $10, M$. avium subsp. silvaticum isolate 0011 ; lane $11, E$. coli $\mathrm{pDI} 13$ after $2 \mathrm{~h}$ induced expression. Lane 11 was taken from an equivalent gel requiring a shorter exposure (20 s compared to $1 \mathrm{~min}$ for lanes 1-10). After transfer to nitrocellulose extracts were probed with the anti-peptide antibody; the HRP-conjugate second-layer antibody was revealed with ECL reagents (Amersham). and the majority was intact in cultures $22 \mathrm{~h}$ after induction. A specific cleavage product was observed at approximately $28 \mathrm{kDa}$, which first appeared between 1 and $2 \mathrm{~h}$ post-induction and was recognized by the antibody. This accumulated to a maximum (at $5 \mathrm{~h}$ ) of approximately $20 \%$ of total detectable p43 (Fig. $5 b$ ).

Though the antibody reacts with the denatured protein on nitrocellulose membranes it repeatedly failed to immunoprecipitate radiolabelled $\mathbf{p} 43$ produced in vitro or to immuno-affinity purify $\mathbf{p} \mathbf{4 3}$ from recombinant bacterial lysates (data not shown).

\section{p43 in M. paratuberculosis}

The anti-CP-1 antibody reacted specifically with a $28 \mathrm{kDa}$ protein present in protein extracts of four strains of $M$. paratuberculosis on Western blot (Fig. 6, lanes 1-4). This product co-migrated with the major cleavage product of the recombinant $\mathbf{4 3}$ from the positive control E. coli (lane 11). In the extract of $M$. paratuberculosis in lane 4 , a faint but sharp band was observed at $45 \mathrm{kDa}$ (particularly on longer exposures); this was interpreted with caution since there was a background smear in this region in the IS900-free $M$. avium (Fig. 6, lanes 7 and 8), though no distinct bands. The $M$. avium and $M$. avium subsp. silvaticum extracts did not show clearly positively staining bands at either $45 \mathrm{kDa}$ or $28 \mathrm{kDa}$.

\section{Discussion}

Coupled transcription-translation of both strands of IS900 (Fig. 2) showed only one identifiable product, p43, corresponding to the predicted molecular mass of the single open reading frame. When the level of transcription was increased by coupling to the tac promoter, an additional band was resolved with a slightly lower apparent molecular mass (Fig. 4). This was observed in all experiments and suggested a post-translational modification of the polypeptide in vitro. Though the doublet was not resolved in Fig. 5 or Fig. 6, it was frequently observed in recombinant $E$. coli in cultures induced for $2 \mathrm{~h}$ or longer (data not shown). The nature of the two components of the doublet is currently under investigation.

The reaction of the specific antibody, generated against a synthetic peptide, with $\mathbf{p 4 3}$ on Western blots (Fig. $5 b$ ) confirmed the correct interpretation of the sequence and assignment of the open reading frame ORF1197 (Green et al., 1989). However, the affinitypurified polyclonal antibody did not recognize the native form of $\mathbf{p 4 3}$ produced in vitro or in vivo. This suggests that the region may be blocked by secondary structure or buried in a pocket or groove inaccessible to an antibody molecule.

As the only product of an insertion element, $\mathbf{p 4 3}$ will almost certainly be responsible for transposition of IS 900 , possibly with the involvement of host cofactors. Detection, by Western blotting, of an immunoreactive $28 \mathrm{kDa}$ protein in all disease isolates of $M$. paratuberculosis, which may be equivalent to the specific cleavage product seen in recombinant $E$. coli (Fig. 6), indicates an unusually high level of expression for a putative transposase. The identity of these two $28 \mathrm{kDa}$ polypeptides is under investigation. Failure to detect the fulllength product is probably due to the slow growth rate of $M$. paratuberculosis and the consequent need to culture for 4-6 weeks in order to obtain sufficient inoculum for protein analysis. The transposase encoded by IS 10 has an experimentally determined abundance of 0.15 polypeptides per cell per generation (Raleigh \& Kleckner, 1986). 
The transposase of $\operatorname{Tn} 3$ was only detectable by SDSPAGE in mutants showing a $10^{4}$-fold increase in translation (Casadaban et al., 1982). As a p43 cleavage product can be detected by Western blotting, it must be expressed at a level several orders of magnitude higher than other transposases. Despite this, transposition of IS900 has not been observed within a strain of $M$. paratuberculosis.

Restriction patterns from various strains of $M$. paratuberculosis isolated in Europe and North America are very similar with only minor variations, which may be accounted for by point mutations affecting individual restriction sites. Some strains have an additional copy of the IS900 element (Levy-Frebault et al., 1989; Whipple et al., 1990). The target-site specificity of IS900 for the sequence $\operatorname{CATG}(\mathrm{N})_{4} \mathrm{CNCCTT}$ may account for the apparent immobility of this element (Green et al., 1989). Assuming a random distribution of bases with $66 \%$ $\mathrm{G}+\mathrm{C}$ content, this sequence would be expected to occur 15-35 times (with a confidence limit of $95 \%$ ) in the $M$. paratuberculosis genome, reported as $3.9 \mathrm{Mbp}$ (McFadden et al., 1987b). The observed copy number of approximately 18-20 (Green et al., 1989) falls in this range. It is conceivable that all the available sites are occupied, as would be expected if the transposase were constitutively expressed. The extra copy observed in some strains of M.paratuberculosis. (Whipple et al., 1990) may be due to a fresh target-site being created through point mutation and then immediately filled. Alternatively, the $28 \mathrm{kDa}$ form of $\mathrm{p} 43$ may be inactive and the fulllength active form may be processed before it can mediate a transposition.

Whether expression of $\mathbf{p 4 3}$ in $M$. paratuberculosis derives from a promoter within IS900 has not been determined. The results of in vitro transcription-translation indicate that there are no functional $E$. coli transcription termination signals in the $5^{\prime}$ non-coding region (Fig. 4). If there are also no mycobacterial transcription termination signals, then one or more copies of IS900 inserted in an active operon in $M$. paratuberculosis would result in expression regulated by the host, which may well be constitutive. It is known, however, that there are signals in mycobacteria which may not function in a species as distant as E. coli (Kieser et al., 1986).

Purification of p43 will provide material to assess its potential as a diagnostic antigen in Johne's disease and for the investigation of potential immune responses in Crohn's disease. In addition, it will facilitate investigation of the mechanism of transposition of IS 900 . This may provide a useful tool for the genetic manipulation of $M$. bovis BCG, which has potential as a recombinant vaccine carrier (Stover et al., 1991; Aldovini \& Young, 1991).
We would like to thank Dr Liz Green for her contribution to the early part of this work. We would also like to thank Dr Fred Rayment (Wellcome Research Laboratories, Beckenham, UK) for supplying the vector pDEV19 and Drs Carolyn Hyde and Ahmed Jehanli for producing the peptide CP-1 and the immobilized peptide. We are grateful to Dr Hazel Griffiths for critical reading of this manuscript. This work was supported by grants from the Wellcome Trust, Action Research and the Ileostomy Association of Great Britain and Ireland, to whom we express our appreciation.

\section{References}

Aldovini, A. \& Young, R. A. (1991). Humoral and cell mediated immune response to live recombinant BCG HIV vaccines. Nature, London 351, 479-482.

Bainton, R., Gamas, P. \& Craig, N. L. (1991). Tn7 transposition in vitro proceeds through an excised transposon intermediate generated by staggered breaks in DNA. Cell 65, 805-816.

Casadaban, M. J., Chou, J. \& Cohen, S. N. (1982). Overproduction of the $\mathrm{Tn} 3$ transposition protein and its role in DNA transposition. Cell 28, 345-354

Cirillo, J. D., Barletta, R. G., Bloom, B. R. \& Jacobs, W. R., JR (1992). A novel transposon trap for mycobacteria: isolation and characterization of IS 1096. Journal of Bacteriology 173, 7772-7780.

Clark-Curtiss, J. E. \& Docherty, M. A. (1989). A species-specific repetitive sequence in Mycobacterium leprae DNA. Journal of Infectious Diseases 159, 7-15.

Collins, M. T., Sockett, D. C., Ridge, S. \& Cox, J. C. (1991). Evaluation of a commercial enzyme-linked immunosorbent assay for Johne's disease. Journal of Clinical Microbiology 29, 272-276.

ENGLAND, P. M., WALL, S. \& MCFADDEN, J. (1991). IS900-promoted stable integration of a foreign gene into mycobacteria. Molecular Microbiology 5, 2047-2052.

Green, E. P., Tizard, M. L. V., Moss, M. T., Thompson, J., Winterbourne, D. J., MCFadden, J. J. \& Hermon-Taylor, J. (1989). Sequence and characteristics of IS900, an insertion element identified in a human Crohn's disease isolate of Mycobacterium paratuberculosis. Nucleic Acids Research 17, 9063-9073.

Guilhot, C., Gicquel, B., Davies, J. \& Martin, C. (1992). Isolation and analysis of IS6120, a new insertion sequence from Mycobacterium smegmatis. Molecular Microbiology 6, 107-113.

Hermans, P. W. M., van Soolingen, D., Dale, J. W., Schuitema, A. R. J., MCAdam, R. A., CatTY, D. \& VAN Embden, J. D. A. (1990). Insertion element IS 986 from Mycobacterium tuberculosis: a useful tool for diagnosis and epidemiology of tuberculosis. Journal of Clinical Microbiology 28, 2051-2058.

Hermon-Taylor, J., Moss, M., Tizard, M., Malik, Z. \& Sanderson, J. (1990). Molecular biology of Crohn's disease mycobacteria. Bailliere's Clinical Gastroenterology 4, 23-43.

Huang, C. J., Heffron, F., Twu, J. S., Schloemer, R. H. \& Lee, C. H. (1986). Analysis of Tn3 sequences required for transposition and immunity. Gene 41, 23-31.

Kieser, T., Moss, M. T., Dale, J. W. \& Hopwood, D. A. (1986). Cloning and expression of Mycobacterium bovis BCG DNA in Streptomyces lividans. Journal of Bacteriology 168, 72-80.

LAEMmLI, U. K. (1970). Cleavage of structural protein during the assembly of the head of bacteriophage T4. Nature, London 227, 680685.

Levy-Frebault, V. V., Thorel, M.-F., Varnerot, A. \& Gicquel, B. (1989). DNA polymorphisms in Mycobacterium paratuberculosis, "Wood pigeon mycobacterium" and related mycobacteria analyzed by field inversion gel electrophoresis. Journal of Clinical Microbiology 27, 2823-2826.

Martin, C., Timm, J., Rauzier, J., Gomez-Lus, R., Davies, J. \& GICQUEL, B. (1990). Transposition of an antibiotic resistance element in mycobacteria. Nature, London 345, 739-743.

McFadden, J. J., Butcher, P. D., Thompson, J., Chiodini, R. \& HERMON-TAYLOR, J. (1987a). The use of DNA probes identifying 
restriction-fragment-length polymorphisms to examine the $\mathbf{M y c o -}$ bacterium avium complex. Molecular Microbiology 1, 283-291.

McFadden, J. J., Butcher, P. D., Chiodini, R. J. \& HermonTAYLOR, J. (1987b). Determination of genome size and DNA homology between an unclassified Mycobacterium species isolated from patients with Crohn's disease and other mycobacteria. Journal of General Microbiology 133, 211-214.

MORISATO, D. \& KLECKNER, N. (1984). Transposase promotes double stranded breaks and single stranded joints at $\mathrm{Tn} 10$ termini in vivo. Cell 39, 181-190.

Moss, M. T., Green, E. P., Tizard, M. L., Malik, Z. P. \& HermonTAYLOR, J. (1991). Specific detection of Mycobacterium paratuberculosis by DNA hybridization with a fragment of the insertion element IS900. Gut 32, 395-398.

Moss, M. T., Malik, Z., Tizard, M. L. V., Green, E. P., Sanderson, J. D. \& HERMON - TAYLOR, J. (1992). IS902, an insertion element of the chronic enteritis causing Mycobacterium avium subsp. silvaticum. Journal of General Microbiology 138, 139-145.

MURPHY, E. (1988). Transposable elements in Staphylococcus; Tn554. Symposia of the Society for General Microbiology 43, 65-71.

New, J. H., EgGleston, A. K. \& FenNwald, M. (1988). Binding of the Tn 3 transposase to the inverted repeats of Tn3. Journal of Molecular Biology 201, 589-599.

Petit, M.-A., Bruand, C., Janniere, L. \& Ehrlich, S. D. (1990). Tn10-derived transposons active in Bacillus subtilis. Journal of Bacteriology 172, 6736-6740.

RALEIGH, E. A. \& KLeCKNER, N. (1986). Quantitation of IS10 transposase gene expression by a method generally applicable to any rarely expressed gene. Proceedings of the National Academy of Sciences of the United States of America 83, 1787-1791.

Sambrook, J., Fritsch, E. F. \& Maniatis, T. (1989). Molecular
Cloning: a Laboratory Manual, 2nd edn. Cold Spring Harbor, NY Cold Spring Harbor Laboratory.

Sanderson, J. D., Moss, M. T., Tizard, M. L. V., Malik, Z., Green, E. P., Rutter, K. \& Hermon-TAYlor, J. (1992). Mycobacterium paratuberculosis DNA in Crohn's disease tissue. Gut (in the Press).

Stover, C. K., De la Cruz, V. F., Fuerst, T. R., Burlein, J. E., Benson, L. A., Bennett, L. T., Banasal, G. P., Young, J. F., Lee, M. H., Hatfull, G. F., SNapper, S. B., Barletta, R. G., Jacobs, W. R., JR \& BLOOM, B. R. (1991). New use of BCG for recombinant vaccines. Nature, London 351, 456-460.

Tanaka, K., Wilks, M., Coates, P. J., Farthing, M. J. G., WalkerSMITH, J. A. \& TABAQCHALI, S. (1991). Mycobacterium paratuberculosis and Crohn's disease. Gut 32, 43-45.

Thierry, D., Cave, M. D., Eisenach, K. D. Crawford, J. T., Bates, J. H.., Gicquel, B. \& GueSDON, J. L. (1990). IS6110, an IS-like element of Mycobacterium tuberculosis complex. Nucleic Acids Research 18, 188

WhipPle, D., KaPKe, P. \& VARY, C. (1990). Identification of restriction fragment length polymorphisms in DNA from $M y c o b a c-$ terium paratuberculosis. Journal of Clinical Microbiology 28, 25612564.

Wiater, L. A. \& GRINDley, N. D. F. (1991). $\gamma \delta$ transposase: purification and analysis of its interaction with transposon ends. Journal of Biological Chemistry 266, 1841-1849.

Vary, P. H., Anderson, P. R., Green, E., Hermon-Taylor, J. \& MCFADDEN, J. J. (1990). Use of highly specific DNA probes and the polymerase chain reaction to detect Mycobacterium paratuberculosis in Johne's disease. Journal of Clinical Microbiology 28, 933-937.

W ISHART, W. L., BROACH, J. R. \& OHTSUBO, E. (1985). ATP-dependent specific binding of $\operatorname{Tn} 3$ transposase to $\mathrm{Tn} 3$ inverted repeats. Nature, London 314, 556-558. 